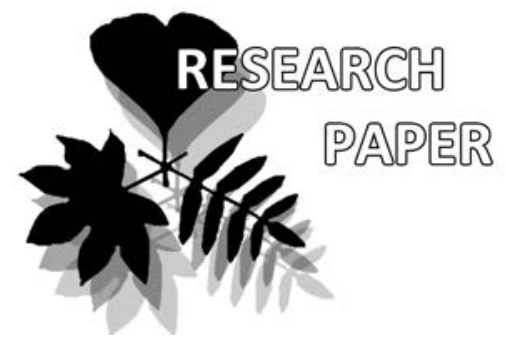

\title{
Notes on the saponins in the plants of the family Hydrocharitaceae
}

\author{
Yana I. Kotelnaya ${ }^{1}$, Elena A. Alekhina ${ }^{1 *}$, Andrey N. Efremov ${ }^{1}$, \\ Yana V. Bolotova ${ }^{2}$, Mariya V. Guselnikova ${ }^{3}$, Svetlana A. Nikolaenko ${ }^{4}$ \\ $\&$ Cezary Toma ${ }^{5}$
}

\author{
Yana I. Kotelnaya ${ }^{1}$ \\ e-mail: janka_55@mail.ru \\ Elena A. Alekhina ${ }^{1}$ \\ e-mail: chemconf@mail.ru \\ Andrey N. Efremov ${ }^{1}$ \\ e-mail: stratiotes@yandex.ru \\ Yana V. Bolotova ${ }^{2}$ \\ e-mail: yabolotova@mail.ru \\ Mariya V. Guselnikova ${ }^{3}$ \\ e-mail: marina_ptukha90@mail.ru \\ Svetlana A. Nikolaenko ${ }^{4}$ \\ e-mail: ns23@mail.ru \\ Cezary Toma \\ e-mail: cezarytoma@poczta.onet.pl
}

${ }^{1}$ Omsk State Pedagogical University, 644099, Omsk, Russia

${ }^{2}$ Amur branch of the Botanical GardenInstitute FEB RAS, Blagoveshchensk, Russia

${ }^{3}$ Surgut State Pedagogical University, Surgut, Russia

${ }^{4}$ Institute of the problems of Northern development SB RAS, Tyumen, Russia

${ }^{5}$ Kazimierz Wielki University, Bydgoszcz, Poland

* corresponding author

Manuscript received: 17.05.2018

Review completed: 15.01.2019

Accepted for publication: 17.01.2019

Published online: 21.01.2019

\begin{abstract}
A B S T R A C T
According to the available literature data, the absence of saponins and sapogenins in the composition could be typical for the representatives of the Hydrocharitaceae family. However, in the study of the component composition, the screening test for saponins gave a positive result. In this regard, studies have been carried out to determine the content of saponins (in terms of glycyrrhizic acid) in the phytomass of some species of the Hydrocharitaceae family (Egeria densa, Elodea canadensis, Hydrilla verticillata, Hydrocharis morsus-ranae, H. dubia, Najas marina, Stratiotes aloides, Vallisneria americana) from different regions of Eurasia. The highest amount of saponins is contained in the phytomass Hydrocharis dubia $(5.1 \pm 0.3 \%), H$. morsusranae $(3.6 \pm 0.5 \%)$ and Stratiotes aloides $(3.4 \pm 0.3 \%)$, the smallest in Elodea canadensis $(1.2 \pm 0.2 \%)$. According to the content of saponins (in terms of glycyrrhizic acid), the studied plants of the family Hydrocharitaceae could be divided into two groups: with the largest (more than $3 \%$ ), interesting as the raw material base, and the smallest (less than $3 \%$ ). On model species, seasonal changes in the content of saponins are confirmed, the content is statistically significantly different by 1.3 times.
\end{abstract}

Ke y w o r d s : Hydrocharitaceae, glycyrrhizic acid, triterpenoid saponins, composition, phytochemistry

\section{P E 3 Ю M E}

Котельная Я. И., Алехина Е. А., Ефремов А. Н., Болотова Я. В., Гусельникова М. В., Николаенко С., Тома Ц. Сапонины растений семейства Hydrocharitaceae. Согласно имеющимся митературным Аанным, Аля преАставителей семейства Hydrocharitaceae характерно отсутствие в их составе сапонинов и сапогенинов. ОАнако, при исследовании компонентного состава скрининг-тест на сапонины Аал положительный результат. В связи с этим были выполнены исследования по определению содержания сапонинов (по гАицирризиновой кислоте) в фитомассе некоторых виАов растений семейства (Egeria densa, Elodea canadensis, Hydrilla verticillata, Hydrocharis morsusranae, $H$. dubia, Najas marina, Stratiotes aloides, Vallisneria americana), полученных из различных районов Евразии. Установлено, что наибольшее количество сапонинов содержится в фитомассе Hydrocharis dubia $(5,1 \pm 0,3 \%), H$. morsus-ranae $(3,6 \pm 0.5 \%)$ и Stratiotes aloides $(3.4 \pm 0.3 \%)$, наименьшее - в Elodea canadensis $(1,2 \pm$ $0,2 \%)$. Исследованные растения семейства Hydrocharitaceae по содержанию сапонинов (в пересчете на глицирризиновую кислоту) можно разделить на Аве группы: с наибольшим (более 3 \%) - интересные с точки зрения сырьевой базы, и наименьшим (менее 3 \%). На модельных видах подтвержАены сезонные изменения содержания сапонинов, содержание статистически значимо отличается в 1,3 раза.

КАючевые слова: Hydrocharitaceae, глицирризиновая кислота, тритерпеновые сапонины, содержание, фитохимия
Traditionally, high molecular glycosides of plant origin of steroid or triterpene nature are classified as saponins with high surface activity (Kurkin 2004). Steroid saponins are usually derived from spirostan or furostan and synthesized from cholesterol (Challinor \& De Voss 2013, Watson \& Dallwitz 2008). Triterpene saponins are synthesized from squalene and contain 30 carbon atoms (Muraviev et al. 2002). A typical representative of triterpene saponins is glycyrrhizic acid (20 $\beta$-carboxy-11-oxo-30-norolean-12-ene$3 \beta$-yl-2-O- $\beta$-D-glucopyranuronosyl- $\alpha-\mathrm{D}$-glucopyranosiduronic acid) (Mahato et al. 1992, Minina \& Kauhova 2004).
Saponins affect the permeability of plant cells, in small concentrations accelerate the germination of seeds, the growth and development of plants, and in large ones inhibit, performing the function of plant growth hormones (Muraviev et al. 2002). Plant saponins exert cardiotonic, neurotrophic, hypotensive, tonic, hypocholesterolemic and antisclerotic, diuretic, corticotropic, adaptogenic, sedative, antiulcer genic and mild laxative effects on human subjects (Hostettmann \& Marston 1995). The most rich in saponins plants are Beta vulgaris L. - 5.8 \%, Glycyrrbiza glabra L. - 22.2$32.3 \%$, Polygala spp. - 8-10\%, Primula spp. - 5-10\%, Quillaja 
saponaria Molina - 9-10 \%, Yucca schidigera Roezl ex Ortgies 10 \%, etc. (Güçlü-Ustündağ \& Mazza 2007, Mir et al. 2016).

According to the published data, the species of the family Hydrocharitaceae Juss. are characterized by the absence of saponins and sapogenins in the composition (Angiosperm 2008, Cook 1992, 1998, Dahlgren et al 1985, Watson \& Dallwitz 2008). It is known that there are diterpenes in Hydrilla verticillata (L. f.) Royle and steroids (sterols) in Vallisneria americana Michx. Elodea canadensis Planch. and Vallisneria americana contain triterpenoids, mainly derivatives of alisol as well (Budantsev 2014). In general, the representatives of the order Alismatatles Dumortier, to which the family of Hydrocharitaceae belong, contain no saponins, although there are species containing diterpenes and some steroids (Budantsev 2014). Steroid saponins in the Alismatatles are known only in the representatives of the family Tofieldiaceae Takhtajan (Angiosperm 2017) and Alismataceae Vent. (Wiart 2012).

However, in the study of the composition of the some species of the family Hydrocharitaceae, the screening test showed a positive result for the presence of saponins ( $\mathrm{Pal}$ \& Nimse 2006, Prabha \& Rajkumar 2015, Mary Kensa \& Neelamegam 2015, Kotelnaya \& Alekhina 2016). In this regard, the purpose of our study was to specify the content of saponins (in terms of glycyrrhizic acid) in the phytomass of plants of species belonging to Hydrocharitaceae.

Some representetives of the family are used in traditional medicine in the countries of Southeast Asia, India and China, for example Hydrocharis dubia (Blume) Backer, Ottelia alismoides (L.) Pers., Blyxa echinosperma (C.B.Clarke) Hook.f. as digestive tonic (Sakong et al. 2011). Ottelia alismoides is also used to treat asthma, urinating difficulty, hydrops, skin diseases and burns, and has an antituberculosis effect ( $\mathrm{Li}$ et al. 1995, Chen et al. 2012). Hydrilla verticillata as a mean to improve digestion and gastrointestinal function, circulation, neurological health, to body resistance and increase endurance (Pal \& Nimse 2006). Stratiotes aloides L. is used for treating wounds, and also of bruised kidneys (Grieve 1984). Enhalus acoroides (L.f.) Royle has an antimicrobial activity (Mahady 2002). Further study of the chemical composition can be used to clarify the systematic position of individual taxa, and to predict the pharmacological properties and use.

\section{MATERIAL AND METHODS}

The samples of the following species of plants of the species Egeria densa, Elodea canadensis, Hydrilla verticillata, Hydrocharis dubia, H. morsus-rana, Najas marina, Stratiotes aloides and Vallisneria americana served as a material for the study. The plants were collected in the phenophases of flowering and fruiting. Data on the location and time of the samples collecting are shown in Table 1.

At the first stage, saponins were detected $(n=5)$ in aqueous extracts by precipitation of lead acetate (II), barium hydroxide and copper salts (II) (Kurkin 2004, Ladygina et al. 1983). The licorice root (Glycyrrhizae radix) - a natural source of saponins listed in the official pharmacopeia was used as a control sample, it contains at least $6 \%$ of glycyrrhizic acid (Avramenko et al. 2015). In all the examined samples saponins was qualitatively confirmed.
The indication of the nature of saponins was carried out on the basis of the foamability reaction (Kurkin 2004). A sample for foamability (Phontan-Kandel's method) was carried out in a measuring test tubes, which made it possible to establish the height of a stable foam. The results are presented in Table 2. The obtained results indicate the presence of the saponins of triterpene nature in the plants of the family Hydrocharitaceae; while the height of a stable foam is 1.5-5.0 times lower in comparison with the control.

Gravimetric, titrimetric and photometric methods are widely used in the specification of saponins in plant materials (Kovalev et al. 2003, Minina \& Kauhova 2004). Most often, color-imetric and spectrophotometric methods of analysis are used to quantify saponins (Kovalev et al. 2003). Since saponins absorb light in the range of $260-280 \mathrm{~nm}$, direct spectrophotometric methods of quantitative analysis are applicable to them (Minina \& Kauhova 2004). The method itself is quite simple and highly accurate, the difficulty of specification saponins lies only in the laboriousness of extracting substances from the phytomass.

For the quantitative analysis at the stage of sample processing, the plants were dried to an air-dry state, powdered and riddled through a sieve with a hole size of $0.25 \mathrm{~mm}$, after which a chemical analysis was carried out. The precise test portion of the raw material was extracted with a $3 \%$ acetone solution of nitric acid and hot acetone, followed by the precipitation of glycyrrhizic acid with a concentrated solution of ammonia. The resulting precipitation was quantitatively dissolved in distilled water (Avramenko et al. 2015). The quantitative analysis of the content of saponins (in terms of glycyrrhizic acid) was carried out by spectrophotometric method using a spectrophotometer "SF-56" (Russia) according to the methodology described in the state pharmacopeia of the Russian Federation (The state 2015). The optical density of the saponin solution was recorded at a wavelength of $258 \mathrm{~nm}$ in cuvettes with an optical layer thickness of $10 \mathrm{~mm}$. The distilled water was used as the reference solution. The analysis was carried out in two replicates, each with two measurements.

The content of glycyrrhizic acid in the studied samples was calculated by the formula:

$X=A \times 822 \times 250 \times 50 \times 100 / a \times 3 \times 11000 \times 1000$, where $A$ is the optical density of solution; $a$ - the precise test portion of raw materials, g; 822 is the molecular weight of glycyrrhizic acid; 11000 is the molar absorption coefficient.

Statistical processing (descriptive statistics, Mann-Whitney U-test) of the results was performed using Statistica 6.1, the results obtained are for $\mathrm{p}=0.95$.

\section{RESULTS AND DISCUSSION}

The content of saponins in samples of the following species of plants of the family Hydrocharitaceae obtained from different regions of Eurasia has been studied, and results are shown in Fig. 1.

Based on the reactions of sedimentation and foamability sampling (according to the Phontan-Kandel's method), the representatives of the family Hydrocharitaceae contain saponins of triterpene nature. Recently Mary Kensa \& Neelamegam (2015), who investigated $H$. verticillata samples from 
Table 1. Information on the studied plant samples

\begin{tabular}{|c|c|c|c|}
\hline Species & The collecting place & $\begin{array}{l}\text { Date of } \\
\text { collection }\end{array}$ & Collector \\
\hline \multirow[t]{3}{*}{ Egeria densa } & Russia, Moscow region, Luberetsky district, the Pehorka River & VI.2016 & A. Efremov \\
\hline & Russia, the Republic of Crimea, Sevastopol, Maxsimova dacha & IX.2016 & S. Halyavina \\
\hline & China, province of Guilin, Yansho, the Lu River & $\mathrm{I} .2017$ & A. Efremov \\
\hline \multirow[t]{3}{*}{ Elodea canadensis } & $\begin{array}{l}\text { Russia, Omsk region, Tavrichesky district, the valley of the Irtysh river, the } \\
\text { Achairka River }\end{array}$ & VII.2015 & A. Efremov \\
\hline & $\begin{array}{l}\text { Russia, Omsk region, Lubinsky district, the valley of the Irtysh river, the untitled } \\
\text { waterbody }\end{array}$ & IX.2015 & A. Efremov \\
\hline & Russia, Tyumen region, Yarkovsky district, the Svetloe Lake & IX.2016 & S. Nikolaenko \\
\hline \multirow[t]{5}{*}{ Hydrilla verticillata } & $\begin{array}{l}\text { Russia, Omsk region, Lubinsky district, the valley of the Irtysh river, the untitled } \\
\text { waterbody }\end{array}$ & IX.2015 & A. Efremov \\
\hline & Russia, Omsk region, Sargatsky district, the Kushaily Reservoir & VIII.2016 & A. Efremov \\
\hline & Russia, Amurskaya region, Bureysky district, the untitled lake & IX.2015 & Ya. Bolotova \\
\hline & China, province of Guilin, Yansho, the Lu River & I.2017 & A. Efremov \\
\hline & China, province of Hongan, Zhangiiajie, the Lishui River & I.2017 & A. Efremov \\
\hline \multirow[t]{7}{*}{$\begin{array}{l}\text { Hydrocharis morsus- } \\
\text { ranae }\end{array}$} & $\begin{array}{l}\text { Russia, Omsk region, Nazyvayevsky district, the environs of the town } \\
\text { Nazyvayevsk, the untitled lake }\end{array}$ & VI.2015 & A. Efremov \\
\hline & $\begin{array}{l}\text { Russia, Omsk region, Lubinsky district, the valley of the Irtysh river, the untitled } \\
\text { waterbody }\end{array}$ & IX.2015 & A. Efremov \\
\hline & Russia, Omsk region, Bolsherechensky district, the untitled waterbody & VIII.2016 & A. Efremov \\
\hline & Russia, Omsk region, Sargatsky district, the Kushaily Reservoir & VIII.2016 & A. Efremov \\
\hline & Russia, Omsk region, Omsky district, the Irtysh River & IX.2016 & A. Efremov \\
\hline & Russia, Altai Republic, Mayminsky district, the Monzherok Lake & VII.2017 & A. Efremov \\
\hline & Russia, Altaiskiy Krai, Kalmansky district, the Eraska Reservoir & VII.2017 & A. Efremov \\
\hline \multirow[t]{2}{*}{ Najas marina } & Russia, Omsk region, Sargatsky district, the Tobol-Kushly Lake & VIII.2016 & A. Efremov \\
\hline & Russia, Tyumen region, Yarkovsky district, the Bolshoe Lake & IX.2016 & S. Nikolaenko \\
\hline \multirow[t]{9}{*}{ Stratiotes aloides } & Russia, Omsk region, Nazyvayevsky district, the untitled waterbody & VII.2015 & A. Efremov \\
\hline & $\begin{array}{l}\text { Russia, Omsk region, Lubinsky district, the valley of the river Irtysh, the untaitled } \\
\text { waterbody \#1 }\end{array}$ & IX.2015 & A. Efremov \\
\hline & $\begin{array}{l}\text { Russia, Omsk region, Lubinsky district, the valley of the Irtysh river, the untitled } \\
\text { waterbody \#2 }\end{array}$ & VII.2016 & A. Efremov \\
\hline & Russia, Omsk region, Bolsherechensky district, the Bolshaya River & VIII.2016 & A. Efremov \\
\hline & Russia, Tyumen region, HMAO-Ugra, Nefteyugansky district, the Seretinskie Lakes & VIII.2016 & A. Efremov \\
\hline & Russia, Tyumen region, Yarkovsky district, the Svetloe Lake & IX.2016 & S. Nikolaenko \\
\hline & Poland, Kuyavian-Pomeranian Voivodeship, the pond & IX.2016 & C. Toma \\
\hline & Poland, Kuyavian-Pomeranian Voivodeship, the Lipkus Lake & IX.2016 & C. Toma \\
\hline & Poland, Pomeranian Voivodeship Slosinko, the Slosinskie Great Lakes & VII.2006 & C. Toma \\
\hline Vallisneria americana & Russia, Moscow region, Luberetsky district, the Pehorka River & VI.2016 & A. Efremov \\
\hline
\end{tabular}

Table 2. Specification of the nature of saponins in plants of the family Hydrocharitaceae

\begin{tabular}{lcc}
\hline Species & $\begin{array}{c}\text { Reaction in acidic } \\
\text { media, sm }\end{array}$ & $\begin{array}{c}\text { Reaction in al- } \\
\text { kaline media, sm }\end{array}$ \\
\hline Stratiotes aloides & 2.0 & 1.6 \\
Elodea canadensis & 3.4 & 3.6 \\
Hydrocharis morsus-ranae & 2.4 & 1.6 \\
Hydrilla verticillata & 1.4 & 1.4 \\
'Glycyrrhizae radix' & 7.0 & 2.2 \\
(control) & & \\
\hline
\end{tabular}

polluted and unpolluted water bodies, also found saponins in water and petroleum ether extracts, as well as steroids in chloroform and petroleum ether extracts in samples of both types.

The results of the specification show that the highest amount of saponins is contained in the phytomass of Hydrocharis dubia (5.1 $\pm 0.3 \%, \mathrm{p}<0.05), H$. morsus-ranae (3.6 $\pm 0.5 \%)$ and Stratiotes aloides $(3.4 \pm 0.3 \%)$, the smallest - in
Elodea canadensis $(1.2 \pm 0.2 \%)$. This allows us to consider the first three species as potential sources of triterpene saponins, although their content does not reach the value of $6 \%$, applied to raw materials used in the state pharmacopoeia (Avramenko et al. 2015).

To estimate the seasonal dynamics (summer, autumn), the model Elodea canadensis, Hydrocharis morsus-ranae, Stratiotes aloides species, which grow in the valley of the Irtysh River, Omsk Region, have been studied (Fig. 2). It was found that Elodea canadensis and Hydrocharis morsus-ranae showed a dissimilarity in content by the end of vegetation by 1.3 times (significance of results is confirmed by the U-criterion).

As it is known, squalene $(2,6,10,15,19,23$-hexamethyltetrakose-2,6,10,14,18,22-hexaene, hydrocarbon belonging to the group of carotenoids) is the precursor of saponins of the triterpenic series in plants (Dekanosidze et al. 1984). The biosynthesis of squalene is carried out from mevalonic acid (3-methyl-3,5-dihydroxyvaleric acid). In the process of biosynthesis, mevalonic acid is converted to farnesyl pyro- 


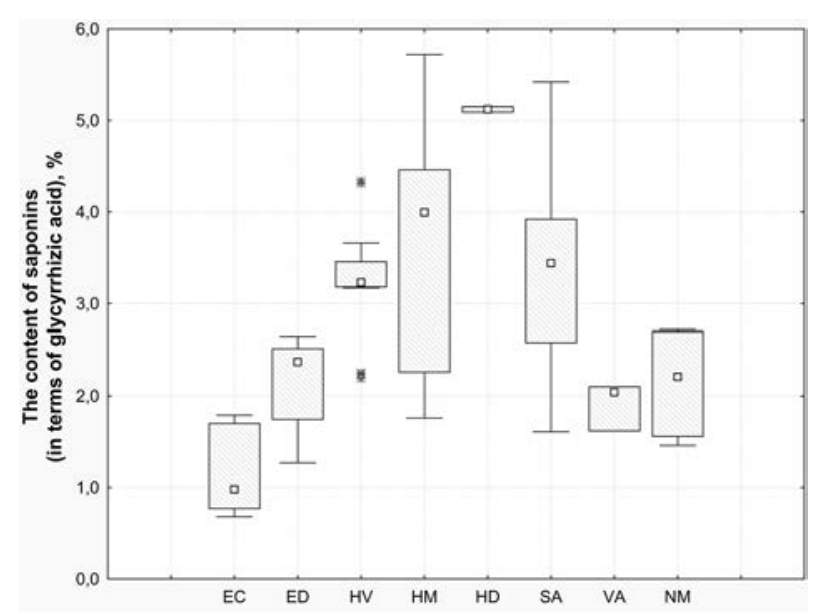

Figure 1 The content of saponins (\% by weight) in plants of the family Hydrocharitaceae $(\mathrm{P}<0.05)$. Note: EC - Elodea canadensis, $\mathrm{ED}$ - Egeria densa, $\mathrm{HV}-$ Hydrilla verticillata, $\mathrm{HM}-$ Hydrocharis morsus-ranae, $\mathrm{HD}$ - H. dubia, NM - Najas marina, SA - Stratiotes aloides, VA - Vallisneria americana

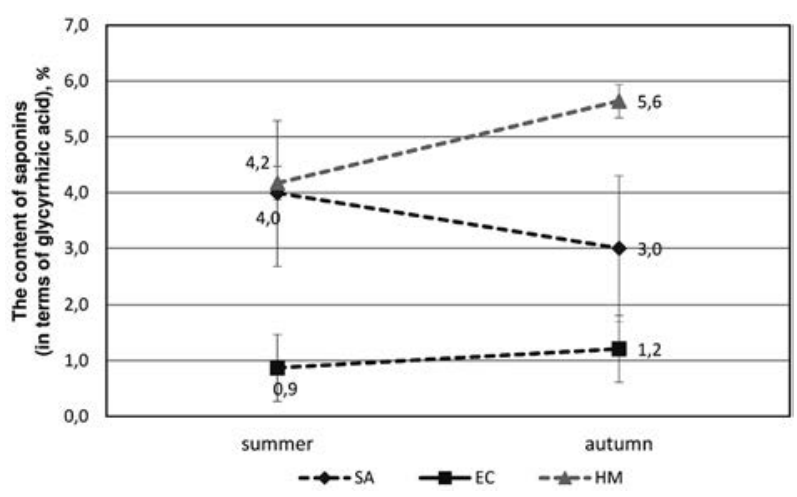

Figure 2 Seasonal changes in the content of saponins ( $\%$ by weight $)$ in plants of the family Hydrocharitaceae $(P<0.05, n=9)$

phosphate, which under squalene synthetase in the presence of thiamine transfers into squalene (Gauptman et al. 1979). The squalene is an intermediate compound in the biological synthesis of steroids, including cholesterol (Dekanosidze et al. 1984). The maximum accumulation of steroids in plants coincides with the period of flowering - the beginning of fruiting (Muraviev et al. 2002), which probably explains the seasonal increase in glycyrrhizic acid content in autumn.

\section{CONCLUSIONS}

According to the content of saponins, the studied plants can be divided into two groups, the significance of the discrepancy in the results is confirmed by the U-criterion. The group I includes species with the highest content of glycyrrhizic acid (more than $3 \%$ ) with semi-submerged (Hydrocharis dubia, H. morsus-ranae, Stratiotes aloides) and submerged biomorphs (Hydrilla verticillata). This group is of interest in terms of raw material base and potential use. The group II includes species with the lowest content of glycyrrhizic acid; these are exclusively species with submerged biomorphs (Egeria densa, Elodea canadensis, Najas marina, Vallisneria americana).

\section{ACKNOWLEDGEMENTS}

We would like to thank for help with collecting material to Svetlana Halyavina (Nikitsky Botanical Garden, the Republic of Crimea). The authors are also grateful to the anonymous reviewer, whose comments improved the manuscript.

\section{LITERATURE CITED}

Amin Mir, M., Kajal Parihar, Uzma Tabasum \& Ekata Kumari 2016. Estimation of alkaloid, saponin and flavonoid, content in various extracts of Crocus sativa. Journal of Medicinal Plants Studies 4(5):171-174.

Angiosperm Phylogeny Website, ver. 9. 2008. http://www. mobot.org/MOBOT/research/APweb/ Last accessed 03.03.2018.

Angiosperm Phylogeny Website, ver. 12. 2017. http://www. mobot.org/MOBOT/research/APweb/ Last accessed 05.08.2017.

Avramenko, G.V., O.G. Potanina \& E.V. Budanova (eds) 2015. The state pharmacopoeia of the Russian Federation, XIII ed. Medicina, Moscow, vol. 3, 1294 pp. (in Russian). [TocyАарственная фармакопея Российской Федерации. XIII изА. / науч. редакторы Авраменко Г.В., Потанина О.Г., Буданова Е.В. 2015. М.: Медицина. Т. 3. 1294 с.].

Budantsev, A.L. (ed.) 2014. Plant resources of Russia, vol. 6. Families Butomaceae-Typhaceae. KMK, Staint-Petersburg, 390 pp. (in Russian). [Растительные ресурсы России. 2014. / отв. реА. А.А. Буданцев. Т. 6. Семейства Butomaceae- Typhaceae. СПб.: КМК. 390 c.].

Cook, C.D.K. Hydrocharitaceae. 1998. In: The families and genera of Vascular plants, vol. 4, Alismatanae and Commelinae, pp. 234-248. Springer, Berlin.

Cook, C.D.K. \& R.A. Lüond 1982. A revision of the genus Hydrocharis (Hydrocharitaceae). Aquatic Botany 14:177-204.

Challinor, V.L. \& J.J. De Voss 2013. Open-chain steroidal glycosides, a diverse class of plant saponins. Natural Product Reports 30(3):429-454.

Chen, Y.-D., X.-T. Ma, Y.-F. Du, M. Feng \& M. Li 2012. The Chinese aquatic plants. Henan Scientific and Technical publishing, Zhengzhou. 479 pp.

Dahlgren, R.M.T., H.T. Clifford \& P.F. Yeo 1985. The families of the Monocotyledons: structure, evolution, and taxonomy. Berlin, Heidelberg, New York, Tokyo. 520 pp.

Dekanosidze, G.E., V.Ya. Chirva, \& T. Sergienko 1984. Biological role, distribution and chemical structure of triterpene glycosides. Micniereba, Tbilisi, 347 pp. (in Russian). [Аеканосидзе Г.Е., Чирва В.Я., Сергиенко Т.В. 1984. БиоАогическая роль, распространение и химическое строение тритерпеновых гликозидов. Тбилиси: Мицниереба. 347 с.].

Gauptman, Z., Yu. Grefe \& H. Remane 1979. Organic chemistry. Himiya, Moscow, 639 pp. (in Russian). [Гауптман 3., Грефе Ю., Ремане Х. 1979. Органическая химия. М.: Химия, 639 с.].

Grieve, A. 1984. Modern Herbal. Penguin, London.

Güçlü-Ustündağ, O. \& G. Mazza 2007. Saponins: properties, applications and processing. Critical Reviews in Food Science and Nutrition 47(3):231-258.

Hostettmann, K. \& A. Marston 1995. Saponins. Cambridge Univ. Press, Cambridge, 564 pp.

Kotelnaya, Ya.V., E.A. Alekhina \& Yu.A. Murashko 2016. Determination of the content of glycyrrhizic acid in 
Stratiotes aloides L. In: Actual problems of chemistry and methods of its teaching at school and in the University, pp. 53-57. OmSPU, Omsk (in Russian). [Котельная Я.И., Алехина Е.А., Мурашко Ю.А. 2016. Определение содержания глицирризиновой кислоты в телорезе алоэвиАном (Stratiotes aloides L.) // Актуальные проблемы химии и методики её преподавания в школе и в вузе. Омск: ОмГПУ. С. 53-57].

Kovalev, V.N., N.V. Popova, V.S. Kislichenko, et al. 2003. Workshop on pharmacognosy. NFaU Zolotie stranitsi, Kharkiv, 512 pp. (in Russian). [Ковалев B.Н, Попова Н.В., Кисличенко В.С. и Ар. 2003. Практикум по фармакогнозии. Харьков: НФаУ Золотые страницы. 512 с.].

Kregiel, D., J. Berlowska, I. Witonska, et al. 2017. Saponin-based, biological-active surfactants from plants. In: Application and characterization of surfactants, https://www. intechopen.com/books/application-and-characterization-of-surfa ctants/saponin-based-biological-active-surfactants-from-plants.

Kurkin, V.A. 2004. Pharmacognosy. OOO “Ofort”, Sam GMU, Samara, 1180 pp. (in Russian). [Куркин B.A. Фармакогнозия. 2004. Самара: ООО «Офорт» СамГМУ, 1180 с.].

Ladygina, E.Y., L.N. Safronich, B.E. Otrjashenkova, et al. 1983. Chemical analysis of medicinal plants. Moscow, 176 pp. (in Russian). [Цадыгина Е.Я., Сафронич А.Н., Отряшенкова В.Э. и Ар. 1983. Химический анализ мекарственных растений. М.: Высш. школа, 176 с.].

Li, H., X. Qu, D. Zhao, Y. Shi, L. Guo \& Z. Yuan 1995. Preliminary study on the anti-tubercular effect of Ottelia alismoides (L.) Journal of Chinese Medicine \& Traditional Chinese Medicine 20:115-116.

Mahady, G.B. 2002. Are medicinal plants a potential alternative for conventional an-tibiotics in animal husbandry? Thai Journal of Phytopharmacy 9(1):50-62.

Mahato, S.B., A.K. Nandy \& G. Roy 1992. Triterpenoids. Phytochemistry 31(7):2199-2249.

Mary Kensa, V. \& R. Neelamegam 2015. Preliminary phytochemical analysis of Hydrilla verticillata (L. f.) Royle. collected from polluted and unpolluted water sources. International Journal of Informative \& Futuristic Research 3(3): 1125-1128.

Minina, S.A. \& I.E. Kauhova 2004. Chemistry and technology of herbal formulation. GEOTAR-MED, Moscow, 560 pp. (in Russian). [Минина С.А., Каухова И.Е. Химия и технология фитопрепаратов. М.: ГЭОТАР-МЕА, 560 с.].

Muraviev, D.A., I.A. Samylina \& G.P. Yakovlev 2002. Pharmacognosy. Medicine, Moscow, 656 pp. (in Russian). [Myравьева А.А., Самылина И.А., Яковлев Г.П. 2002. Фармакогнозия. М.: Медицина, 656 с.].

Pal, D.K. \& S.B. Nimse 2006. Little known uses of common aquatic plant, Hydrilla verticillata (Linn. f.) Royle. Natural Product Radiance 5(2): 108-111.

Prabha, P.S. \& J. Rajkumar 2015. Phytochemical screening and bioactive potential of Hydrilla verticillata. Journal of Chemical and Pharmaceutical Research 7(3):1809-1815.

Sakong, P., T. Khampitak, U. Chaon, Ch. Pinitsoontorn, P. Sriboonlue, P. Yongvanit \& P. Boonsiri 2011. Antioxidant activity and bioactive phytochemical contents of traditional medicinal plants in northeast Thailand. Journal of Medicinal Plants Research 5(31):6822-6831.

Vasilyeva, I.S. \& V.A. Paseshnichenko 2000. Steroid glycosides and cultures of Dioscoreae cells, their metabolism and biological activity. Uspehi biologicheskoi bimii 40(6): 153-204 (in Russian). [Васильева И.С., Пасешниченко B.A. 2000. СтероиАные гликозиды и культуры клеток Аиоскореи, их метаболизм и биологическая активность // Успехи биологической химии. Т. 40, № 6. C. 153-204].

Watson, L., \& M.J. Dallwitz 2008. Hydrocharitaceae Juss. In: The families of flowering plants: descriptions, illustrations, identification, and information retrieval, ver. 10.04.2008. http://delta-intkey.com./angio/www / hydrocha. htm/.

Wiart, Ch. 2012. Medicinal plants of China, Korea, and Japan: bioresources for tomorrow's drugs and cosmetics. CRC Press, $454 \mathrm{pp}$. 